\title{
Competencies for the effective management of legislated business rehabilitations
}

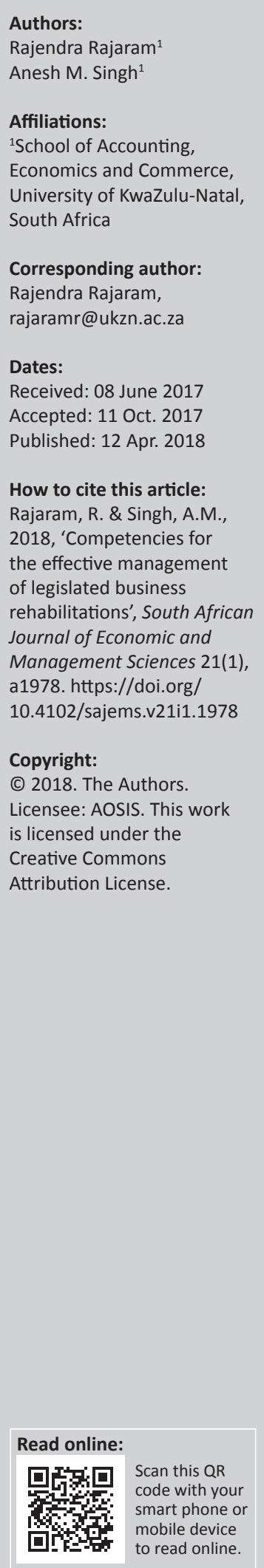

Background: In 2011 a new Companies Act (No. 71 of 2008) was implemented in South Africa. A feature of this Act was the introduction of business rescue legislation. Although this legislation was implemented in May 2011, statistics indicate that the success rate for business rescues is approximately only $12 \%$. This low success rate prompted debate relating to the effectiveness, and continued suitability of a legislated business rescue as a mechanism to rehabilitate financially distressed companies. A feature of the business rescue environment in South Africa is the lack of knowledge, necessitating more research in the field.

Aim: Due to the importance of the business rescue practitioner in the overall success of a rescue, the research focused on establishing competencies required to be a successful practitioner.

Setting: The research was undertaken in South Africa between 2015 and 2017.

Methods: A mixed methods research approach was utilised to identify the important competencies of a successful practitioner. A survey was conducted with the membership of the Turnaround Management Association of Southern Africa. The survey was mailed to 130 members and the response rate was $54 \%$. The survey was complemented by undertaking interviews with 7 of the top 10 business rescue practitioners, according to their number of practitioner appointments.

Results: The original contribution to knowledge of this study is the identification of a set of competencies that can be utilised to accredit business rescue practitioners and the emphasis on an accounting qualification and effective cash management skills that a successful practitioner must possess.

Conclusion: The knowledge generated from this research will benefit business rescue practitioners, the financial sector and stakeholders of companies intending to go into a legislated business rehabilitation.

\section{Introduction}

Financial distress was originally defined by Beaver in 1966 as bankruptcy, insolvency, liquidation, a default on loan obligations or the inability to meet dividend payments (1966 in Muller, SteynBruwer \& Hamman 2012:24). Outecheva (2007) undertook an empirical analysis of distress risks and compiled several definitions of financial distress. Some of these definitions refer to financial distress as a likelihood of bankruptcy, a default on a debt situation and an intermediate state between solvency and insolvency.

Based on the definitions by Beaver and Outecheva, financial distress is characterised by a lack of resources that results either in an involuntary business closure or an attempted restructure. Financial distress occurs when a firm's promises to creditors are broken or are honoured with difficulty. It may result in dismantling and selling the firm's assets (Senbet \& Wang 2012:7). Whilst the liquidation of a business is one of the adverse outcomes of financial distress, many financially distressed firms can be financially rehabilitated. Wang and Shiu (2014:233) noted that some financially distressed firms will experience a rebirth. This rebirth or resurrection phase is commonly referred to as a turnaround (Baird 2014:19).

There are many countries that have adopted a legal framework to facilitate the turnaround and continued existence of financially distressed firms. The South African business rescue legislation defines financial distress as a situation in which a company is reasonably unlikely to be able to pay all of its debts as they become payable and due within the immediate ensuing 6 months, or it appears to be reasonably likely that the company will become insolvent within the immediate 
ensuing 6 months (RSA 2008:128). The main aim of the legislation is to facilitate the rehabilitation or turnaround of a financially distressed company. According to Corporate Renewal Solutions (2012), informal turnarounds have the greatest success due to the informal nature of the process and the fact that it is not subject to legislation. As the process to rehabilitate the distressed company becomes more formal and legal, the situation becomes more inflexible and expensive.

According to Blazy, Martell and Nigam (2011:2), a private or informal restructuring is not always a preferred solution, albeit less costly and quicker than the legislative process to rehabilitate business. There are several reasons why stakeholders will sometimes prefer a costlier and formal legislative procedure. These relate to the 'holdout problem', when individual creditors will hold out from accepting an agreement in the hope that other creditors will accept an agreement for a proposal. There may also be different objectives between various creditors, leading to the formation of coalitions and conflicts of interest which prevent a common agreement on the rescue of a company. Another reason for creditors preferring a formal court approved rehabilitation is the perception that there is a lack of transparency which can only be restored by a court (Blazy et al. 2011:6-7). In recent years, there has been an increase in international insolvency systems that adopted formal mechanisms to aid financially distressed companies engaged in reorganisation (Pretorius \& Rosslyn-Smith 2014:109).

Bradstreet (2010:201) highlighted the importance of effectively managing a formal and legislated business rescue. His contention was that the functions and terms of appointment of the practitioner are of utmost importance when assessing the overall merit and success of the business rescue process. The appointment of a strong business rescue practitioner is a key success factor in business rescues (Bezuidenhout 2012:25). His research established that the key success factors in a rescue are strong and strategic leadership, a strategic plan, a measureable action plan and a motivated management team. Levenstein (2011) concurred with these views by emphasising the vital role of the business rescue practitioner in the success of a business rescue. The assertions about the practitioner's contributions to the success of the business rescue are supported by international research. For example, research into the Finnish Restructuring of Enterprises Act identified management of the restructure, combined with cash generation, as being significantly more important in the successful rescue of a business (Collett, Pandit \& Saarikko 2014:134).

Section 138 of the Companies Act (No. 71 of 2008) deals with the qualifications of the business rescue practitioner and states that a person may only be appointed as a business rescue practitioner if that person is a member in good standing of a legal, accounting or business management profession accredited by the Companies and Intellectual Property Commission (CIPC). In addition, a person can only be appointed as a business rescue practitioner if they are not disqualified from acting as a director and are not subject to an order of probation. Currently, a business rescue practitioner's appointment must be approved by the CIPC that needs to issue an interim conditional licence for the specific company that has applied for business rescue (Terblanche 2014:3).

There are no clear criteria or prerequisites in terms of skill or experience for appointing a business rescue practitioner, other than those highlighted in the discussion on Section 138 (Pretorius 2013a:4). As the authority that regulates the appointment of business rescue practitioners, the CIPC urgently needs to adopt a framework for the licensing of business rescue practitioners (Pretorius 2013a:24). Although the CIPC is considering addressing this issue by establishing an accredited competency framework for the licensing of business rescue practitioners, a stipulated time frame has not been provided yet (Terblanche 2014:3). Given the emphasis on the importance of the management of business rescue and the focus on the business rescue practitioner, it is concerning that the South African regulatory authorities have not established a regulatory authority for the accreditation of business rescue practitioners. The regulatory authority can function on a similar basis to that of the auditing profession which has specific skills and practical experience requirements (Pelser 2012:1). The appointment of a regulatory body is especially important in light of some of the complaints about certain business rescue practitioners who lack the skills to successfully rehabilitate a company that experiences financial distress (Pretorius 2014:2). Such a body could ensure that there is a well-defined set of accreditation criteria to ensure that the practitioner is equal to the task of the stipulated responsibilities.

A major oversight in the appointment of business rescue practitioners is the absence of a procedure for their accreditation. An accreditation process will alleviate some of the concerns relating to the competency of business rescue practitioners, the exorbitant fees they charge, the inability to complete the task on time and shortcomings relating to practitioners adhering to the reporting requirements (Voller 2011).

\section{Literature review}

The lack of a proper accreditation system for business rescue practitioners has resulted in several criticisms of South African business rescue practitioners. As mentioned, these relate to poor quality of work and exorbitant fees charged (Pretorius 2013a:2), the inability to complete tasks in a timely manner and a lack of adherence to reporting requirements (Voller 2011). The business rescue practitioner has also been cited as a cause for failure to attract post rescue funding. Du Preez (2012:156), when analysing barriers to post commencement finance for a company undergoing business rescue, highlighted the concern of industry specialists over the inability of the business rescue practitioner to prepare an adequate business rescue plan that will attract funding. 
According to Midanek (2002), successful turnaround managers require 'war-zone' experience. In order to turn around a financially distressed business, it is vital for the turnaround manager to have appropriate competencies (Obiajunwa 2014:71). Baird (2014), when highlighting the importance of a turnaround manager, linked the economic monetary value of a distressed business to the probability of a successful turnaround in the following equation:

Economic Monetary Value = Probability of Successful Turnaround * Value of the Distressed Business.

The above equation demonstrates the value of appointing a successful business rescue practitioner to a financially distressed business. It illustrates the economic value created when a financially distressed company is successfully rehabilitated. Due to the role of the business rescue practitioner in the success of a rescue, it follows that the appointment of a competent practitioner will enhance the monetary value of the distressed business. The appointment of a competent practitioner will be facilitated by the establishment of accreditation criteria.

The benefit of establishing an accreditation framework, specifying the competencies of a business rescue practitioner, is that the risk of appointing an unsuitable professional as a practitioner is reduced. A suitably accredited practitioner will contribute towards the survival of a distressed firm, thereby enabling the continued existence of the firm (Baird 2014:6). Whilst it is concerning that the CIPC has failed to establish sound criteria for the accreditation of practitioners in South Africa, the difficulty in establishing these accreditation criteria must be acknowledged. The practitioner's tasks are complex, vaguely stated and involve a wide range of competencies that the average business person does not have (Pretorius 2013a:1). It is difficult to determine the optimal competence for a successful business rescue practitioner as it entails various characteristic, educational and experiential traits.

White (1959, cited in Delmarie de List \& Winterton 2005:31) is credited for introducing the term competence to describe personality characteristics associated with superior performance and high motivation. Further recent research in relation to the effective performance of individuals in the workplace suggests that competencies include any individual characteristic that can be measured or counted reliably and that can be shown to differentiate between superior and average performers, or between effective and ineffective performers. Examples of these characteristics include motives, traits or knowledge (Spencer \& Spencer 1993:4). Furnam and Mansi (2011) described a competency as a state of being qualified, capable or proficient through skills, having the knowledge and ability for a specified assignment. A professional competency is described as a composite of personal attributes (capacities, motives, personality traits, self-image, aptitudes, values and personality) which complement themselves with knowledge, abilities, skills, values, actions and experience of the professional task being undertaken (Guerrero \& De los Ríos
2012:9). The establishment of competencies for a successful business rescue practitioner will enhance the knowledgebased resources of a distressed firm.

\section{Business rescue practitioner competencies}

In an effort to establish a set of characteristics that define a successful and high performing turnaround management professional (TMP), Baird (2014:8) explored a missing link in the Dynamic Capabilities Theory relating to human capital and its impact on competitive advantage. Dynamic capability is defined as the firm's ability to integrate, build and reconfigure internal and external competencies to address rapidly changing environments (Teece, Pisano \& Shuen 1997). An important component of the Dynamic Capabilities Theory suggests that human capital of turnaround firms will provide a competitive advantage in the form of knowledge, skills and experience of individuals (Baird 2014:33).

Baird (2014:83) undertook research to identify the characteristics of high performing, successful turnaround management professionals. He sought to expand on the work of the turnaround industry which identified knowledge in the areas of accounting, finance, legal and business acumen and, coupled with experience, as characteristics of successful turnaround practitioners (Turnaround Management Association [TMA] 2012, cited in Baird 2014:4). The initial survey conducted with presidents of turnaround organisations identified the following characteristics as important measures of success in relation to a turnaround management professional (Baird 2014:85):

- Level of ability to communicate transparently and quickly with all stakeholders.

- Ability to implement effective cash management strategies.

- Amount of increase in the distressed company's profitability achieved and speed with which results were achieved.

The second phase of Baird's research involved the utilisation of a questionnaire completed by turnaround management professionals to identify characteristics of a successful turnaround practitioner. The results of his research are illustrated in Figure 1 (Baird 2014:125).

Figure 1 demonstrates that a successful turnaround manager requires a unique combination of educational, experiential and personality skills to be a successful turnaround management professional. Due to the overlap in the objectives between turnarounds and business rescue discussed earlier, these findings can be used as a basis, after suitable adaptation to meet South African conditions, for the much-needed accreditation of a business rescue practitioner.

In order to recommend competencies and educational requirements to achieve these competencies to the CIPC, Pretorius (2013a) initially focused on the important tasks and activities of the business rescue practitioner. He concluded that the five important tasks that must be undertaken by 


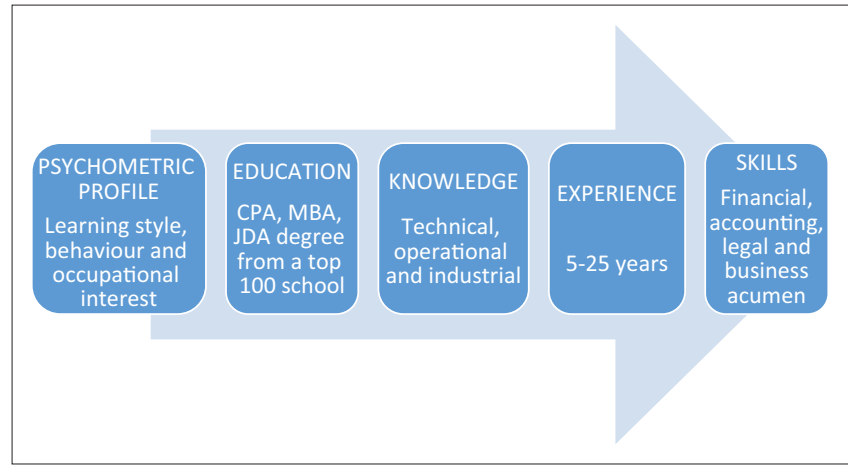

Source: Baird, S., 2014, 'An empirical investigation of successful, high performing turnaroun professionals: Application of the dynamic capabilities theory', unpublished PhD dissertation, Georgia State University, Atlanta, GA.

FIGURE 1: Factors leading to turnaround manager success.

TABLE 1: Focus of research.

\begin{tabular}{ll}
\hline Existing research & Research focus \\
\hline $\begin{array}{ll}\text { Pretorius (2014) undertook research to identify } \\
\text { the competencies required to effectively perform }\end{array}$ & $\begin{array}{l}\text { The research seeks to build on } \\
\text { existing literature by identifying } \\
\text { the main tasks and activities of a business rescue } \\
\text { practitioner. The study established that }\end{array}$ \\
$\begin{array}{l}\text { sense-making, decision-making and integration } \\
\text { andills that are required to } \\
\text { are the most important competencies for }\end{array}$ & $\begin{array}{l}\text { be successful business rescue } \\
\text { practitioner. }\end{array}$ \\
$\begin{array}{l}\text { business rescue practitioner success to } \\
\text { successfully rehabilitate a financially distressed } \\
\text { entity (Pretorius 2014:10). These competencies }\end{array}$ \\
$\begin{array}{l}\text { are achieved through collaboration as the } \\
\text { central competency. }\end{array}$ \\
$\begin{array}{l}\text { The existing literature does not specify the } \\
\text { qualifications required to be a successful } \\
\text { business rescue practitioner. }\end{array}$ \\
\hline
\end{tabular}

a successful business rescue practitioner are taking management control, investigating the affairs of the distressed firm, compiling a rescue plan, implementing this plan and complying with the statutory plan. Thereafter, in an effort to identify the most important activities of a business rescue practitioner, he expanded each of the tasks into an activity. According to Jarzabkowski, Balogun and Seidi (2007), a practice relates to the cognitive, behavioural, procedural, discursive, motivational and physical resources that practitioners combine and use in the performance of their responsibilities. The research indicated that there are five activities undertaken by business rescue practitioners that contribute to $55 \%$ of their total activity. These important activities are undertaking a viability analysis (14\% of the total activity of a business rescue practitioner), conducting a feasibility analysis (9\%), meeting with stakeholders (11\%), preparing a rescue plan $(8 \%)$ and following the rescue process $(14 \%)$

Further research, conducted by Pretorius (2014:10) to identify the competencies required by the business rescue practitioner to successfully complete tasks and activities, concluded that the most important competencies are sense-making, decisionmaking and integration. These competencies are to be achieved through collaboration, which was considered to be the central competency. However, there is an absence of literature relating to the educational qualifications that will contribute towards a competent practitioner (Table 1).

As reflected in Table 1, there exists a research gap due to the absence of literature relating to the qualifications that a successful business rescue practitioner must possess.
According to Guerrero and De los Ríos (2012:9), knowledge forms an important component of the successful execution of a professional task. According to Section 138 (a) of the Companies Act (RSA 2008), a person may be appointed as a business rescue practitioner if they are a member in good standing of a legal, accounting or business management profession accredited by the CIPC. A shortcoming of existing literature is that guidance is not provided on the most suitable educational qualification that will result in a competent practitioner. Although research on business rescue practitioners indicated support for an examination and a formal qualification as a prerequisite for practitioner appointments, existing literature has provided no guidance on the suitable scope of the qualification or the content of the examination (Pretorius 2015:92).

\section{Research methodology}

A key finding of the literature review was an absence of academic literature on the qualifications of a successful business rescue practitioner and hence the need to undertake empirical research to develop knowledge in this field. This shortcoming in the literature has resulted in the inability to rank educational competencies required to be a successful business rescue practitioner.

These limitations provided justification to engage in further research to extend the literature of business rescue. The empirical study therefore focused on developing a set of qualifications required to be a successful business rescue practitioner in South Africa.

\section{Research design}

In order to meet the objectives of the research and to harness and develop new knowledge in the field of business rescue, it was important to adopt a complementary mixed methods approach to satisfy the research objectives. A complementary mixed methods approach entails the use of both a quantitative and a qualitative approach. The usage of this approach is supported by Creswell (2003:17) as a means to achieve research rigour. It is a sound principle of research to view qualitative and quantitative research as being complementary, rather than in competition with each other (Malhotra 2004:137). The researcher therefore decided that the use of a mixed methods approach would follow different paths to establish the competencies that are required to be a successful practitioner (Gerring 2008).

Having justified the need for a mixed methods approach to meet the research objectives, it was important for the research design to reflect a comprehensive strategy that would solve the research problem (Leedy \& Ormrod 2001:91).

\section{Quantitative research Questionnaire design}

The questionnaire, comprising closed-ended questions, was used to address the objectives of this study. The questionnaire 
was answered by the members of the TMA-SA, a group of turnaround and business rehabilitation experts. The questionnaire required the TMA-SA membership to:

- Rank the first and second most important qualification that a business rescue practitioner should possess.

- Rank the first, second and third most important skill that a business rescue practitioner must possess.

- Provide and explain their views on the necessity of an exam to become an accredited business rescue practitioner.

The data were analysed using graphical statistics (bar graphs and frequency tables) and inferential statistics (chi-square tests of independence and non-parametric tests such as Mann Whitney U tests).

\section{Qualitative research}

For the qualitative research, 7 of the top 10 business rescue practitioners were interviewed. An advantage of the interview was that the researcher could gain considerable insight from each business rescue practitioner based on their personal experience.

There are disadvantages associated with using in-depth interviews as an instrument for data collection. The results are dependent on the researcher's interpretation and it is an expensive process to conduct interviews (Zikmund et al. 2013). A specific disadvantage of conducting interviews with business rescue practitioners for this study was that professionals do not have sufficient time and they are dispersed in different geographic locations. This difficulty could be overcome by conducting telephonic interviews (Baird 2014). The interview schedule was emailed to the interviewees so that they could familiarise themselves with the questions. Thereafter, a convenient time was agreed for the interview.

\section{Research instrument}

The interviews with business rescue practitioners were able to establish information that could be utilised to meet the research objectives. The interview schedule was constructed in a manner that would obtain feedback from the top 10

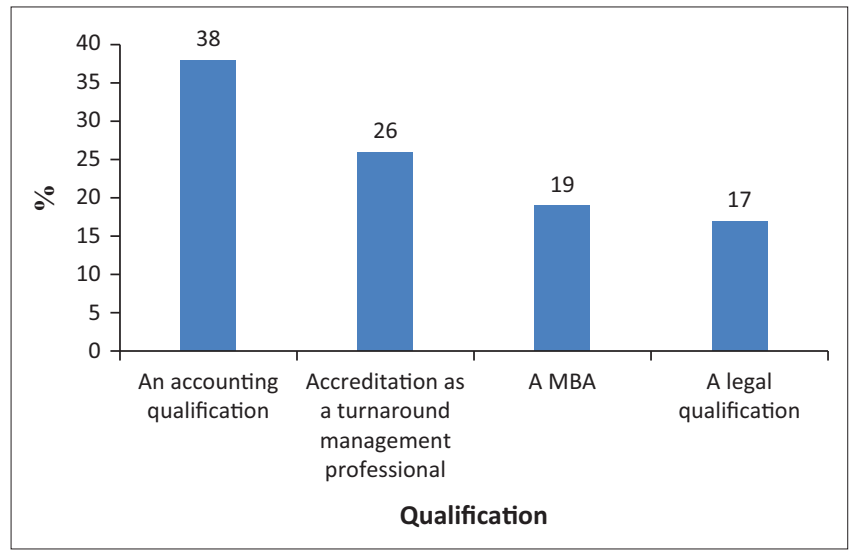

FIGURE 2: Important qualifications required to be a successful business rescue practitioner. business rescue practitioners relating to the competencies of a business rescue practitioner. The following questions were asked:

- What impact will the establishment of accreditation criteria for business rescue practitioners have on a business rescue?

- What are some of the competencies or qualifications that a successful business rescue practitioner should possess?

- Who should establish the accrediting body?

The duration of each interview was approximately $1 \mathrm{~h}$ and it was recorded for analysis. The data was analysed using content analysis.

\section{Discussion of findings Qualifications that a practitioner should possess}

The first question of the survey required responses to the two most important qualifications required to be a successful business rescue practitioner. The feedback is illustrated in Figure 2.

According to Figure 2, an accounting qualification had the highest average ranking of $38 \%$. Although the identification of an accounting qualification as the most important qualification for business rescue practitioners represents a new contribution to knowledge in business rescue, it does support the focus on effective cash management of a financially distressed business that was highlighted in existing literature (Mindlin 2013; Pretorius 2012).

Possession of an accounting qualification will also facilitate the development of an improved business rescue plan. Pretorius (2012) noted that fewer than 50\% of business rescue plans contained sufficient details relating to projected cash flow statements, balance sheets and income statements, which has negative consequences for the success of a business rescue plan and the business rescue. Business rescue practitioners who have an accounting qualification will therefore contribute significantly to compiling the business rescue plan and the chances of raising post rescue finance.

Approximately $26 \%$ of the respondents ranked the accreditation of a turnaround management professional as the most important skill that a successful business rescue practitioner should possess. Whilst Section 138(a) of the Companies Act (RSA 2008) allows for the appointment of a business rescue practitioner if the person is a member in good standing of a legal, accounting or business management profession accredited by the CIPC, it does not include turnaround management accreditation or experience. In order to successfully rehabilitate a financially distressed company, the practitioner requires 'war-zone' experience (Pretorius 2013b:1). An accredited turnaround management professional will possess the necessary skills to restore profitability to financially distressed companies. Baird (2014) noted that successful turnaround management professionals possess the necessary psychometric profile, educational, 
knowledge and experience to implement a successful turnaround strategy. His research findings acknowledge the vast spectrum of responsibilities relating to negotiation, cash flow management, strategy, conflict resolution and administration required by the business rescue practitioner.

A Levene's test for the equality of variances was conducted to investigate if significant differences exist between an accounting qualification and accreditation as a turnaround management professional. The test statistic of 3.125 and a $p$ value of 0.047 indicated that there was a significant difference between these variances.

A legal qualification was ranked as the least important qualification. Although the business rescue process is nonjudicial and commercial in nature, there remains a high reliance on courts to ensure compliance (Ensor 2014). There are concerns relating to the legal skills of South African courts to handle business rescue disputes (Visser 2013). These concerns point to the need for special legal qualifications relating to business rescue during disputes or judicial matters rather than in the performance of a business rescue practitioner's responsibilities.

Overall, it can be concluded that a successful business rescue practitioner must possess an accounting qualification or be an accredited TMP. In addition to a qualification, a successful business rescue practitioner must possess certain important skills, as discussed next.

\section{Skills that a business rescue practitioner should possess}

The second question related to the three most important skills required to be a successful business rescue practitioner. The results of the most important skills are presented in Figure 3.

According to Figure 3, a strong sense of decision-making was ranked as the most important skill. The ability to implement effective cash management strategies and a strong aptitude for success were regarded as the second and third most important skill respectively. A Levene's test on the equality of

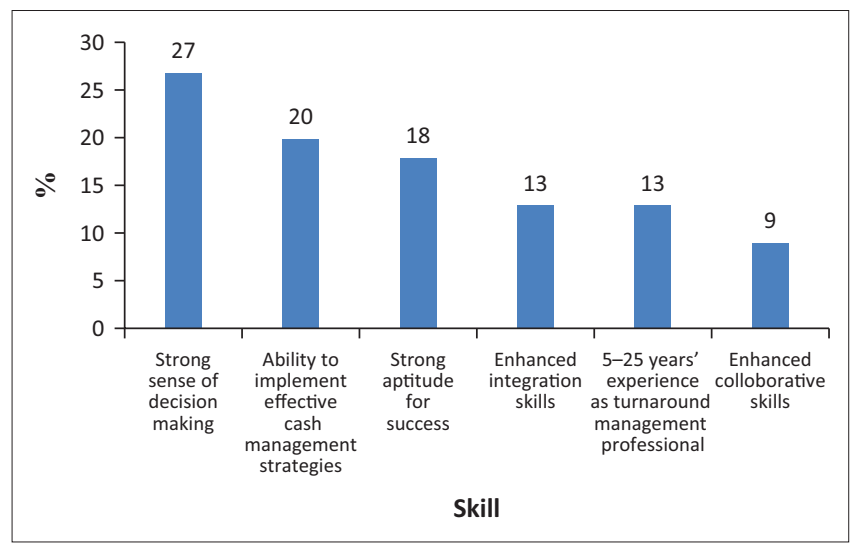

FIGURE 3: Important skills required to be a successful business rescue practitioner. variances was conducted on the second and third most important skill. The results indicated that there is no significant difference in the variance of these skills.

Effective cash management relates to the raising of postrescue funding and the effective management and utilisation of cash resources during a rescue.

Existing literature supports the generation of cash as vital to a successful turnaround or business rescue (Carter \& Van Auken 2006; Du Preez 2012; Mindlin 2013; Vriesendorp \& Gramatikov 2010). In the USA, a feature of the Chapter 11 rescue mechanism is the availability of funding, which is viewed as a reason for many successful rescues (Bharath, Panchaegesan \& Werner 2013:10). A business rescue practitioner who is skilled in implementing effective cash management strategies will contribute to the overall success of the rescue. This finding is highly consistent with the finding that a business rescue practitioner must possess an accounting qualification.

Another important skill that that was identified was the 5 to 25 years of experience as a turnaround management professional. It is consistent with the earlier finding on the importance of a qualification as a TMP.

These findings, however, contradict earlier research which concluded that enhanced collaborative skills are the central and most important competency that a business rescue practitioner must possess (Pretorius 2014). This study has ranked that skill as the least important.

In an effort to develop a framework for the accreditation, a further question dealt with the need for a written examination.

\section{Need for an accreditation examination}

The final quantitative question related to the necessity of a written examination as part of the accreditation process. The results are presented in Figure 4.

It is evident from Figure 4 that the majority (56\%) are in favour of a written examination to improve the competencies of business rescue practitioners. A written exam can be used as a mechanism in the accreditation process to address some of the concerns relating to the poor skills of practitioners (Ensor 2014; Pretorius 2013a). The finding that a written examination is necessary supports existing literature relating to this necessity (Pretorius 2015:92). Although the margin of $12 \%$ represented a small majority in favour of a formal accreditation examination, it must be noted that a test for the difference between the two proportions indicated a significant difference between those respondents in support of a written exam and those not in support.

\section{Impact of establishing accreditation criteria for business rescue practitioners}

A consensus view of interviewees is that the establishment of accreditation criteria will have an extremely positive impact 


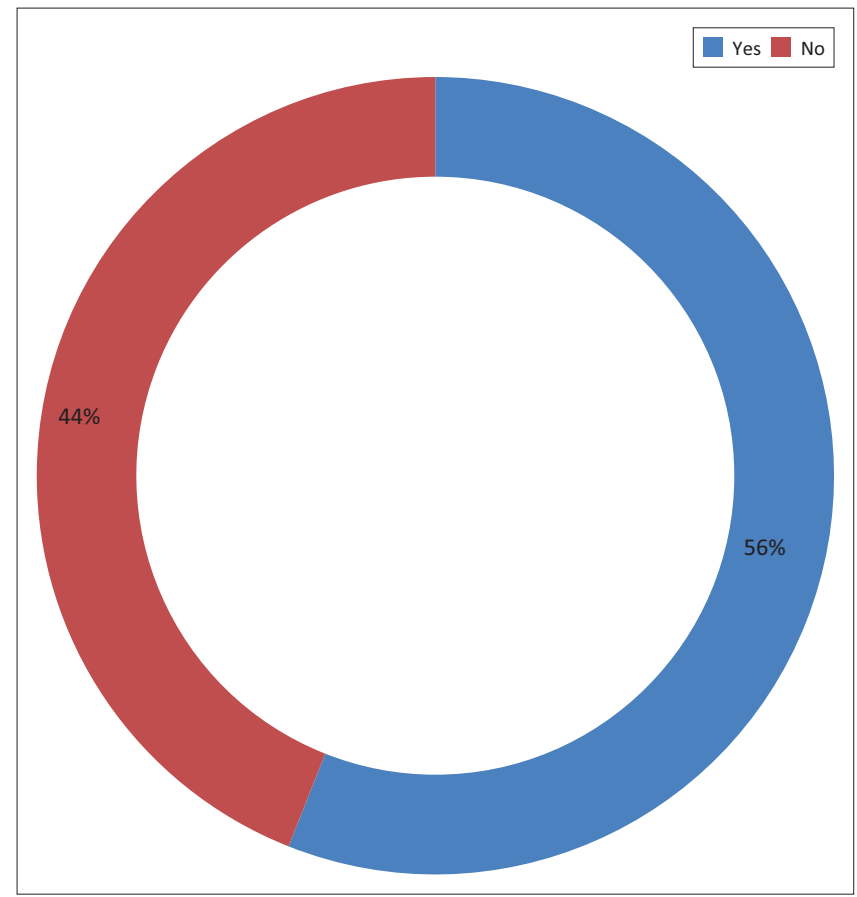

FIGURE 4: Need for a written examination.

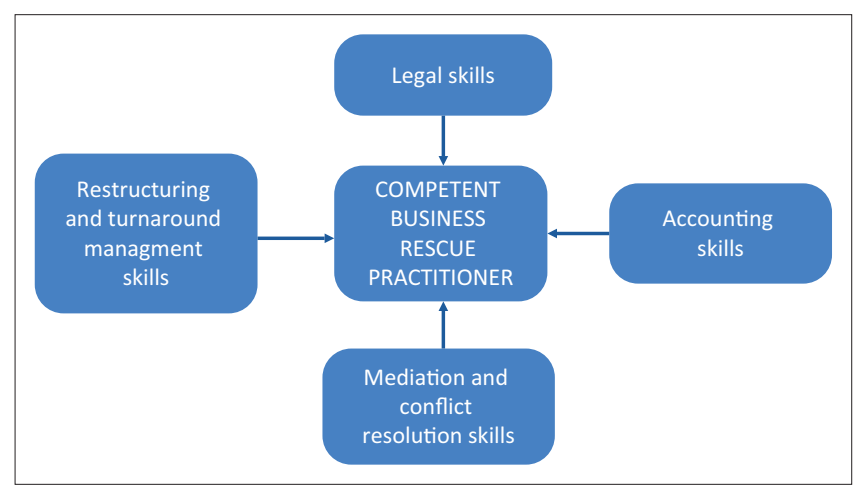

FIGURE 5: Competencies required to be an effective business rescue practitioner.

on the business rescue sector. This view was driven by a recognition that the responsibilities and tasks of a business rescue practitioner are distinctly different from any other profession. Therefore, a separate skills set is required to become a successful business rescue practitioner. An accreditation framework consisting of strict criteria will equip business rescue practitioners with the necessary skills to ensure successful business rescues. Some interviewees suggested that the accreditation process is essential and not negotiable. They pointed to their experience of many unsuitable practitioners that appear on the CIPC panel. The establishment of accreditation criteria will rectify this adverse situation.

There is thus no doubt that the establishment of accreditation criteria will have a positive impact on business rescue. It will legitimise the profession and increase the potential for successful business rescues. An improvement in the expertise and qualifications of business rescue practitioners will improve the effectiveness of practitioner performance.

\section{Essential competencies for successful business rescue practitioners}

This question served to build on the previous question relating to the necessity of accrediting business rescue professionals. Responses to this question can generate knowledge in support of the research objective to develop a set of competencies required to be a successful business rescue practitioner. The interviewees indicated that an individual who possesses only a single skill (such as only a legal or accounting skill) will not be a successful business rescue practitioner. It was evident that the interviewees view a successful business rescue practitioner as having a multitude of skills and qualifications. A successful business rescue practitioner must possess effective legal, restructuring, accounting, and mediation and conflict resolution skills (Figure 5).

The legal skills must not be of a general nature or focused on an area that is not related to financial distress or corporate rehabilitation. The skills must be related to contractual, company and insolvency law. A person trained as a criminal lawyer only will not possess the necessary legal skills for business rescue. In addition to the legal skills, a successful practitioner must possess accounting and financial skills to sufficiently understand and assess the financial performance of the distressed business. The accounting skills must specifically relate to the rehabilitation of a business. The skills must enable the practitioner to facilitate the rehabilitation and to generate cash for the distressed entity.

In addition to possessing relevant legal and accounting skills, it is important for a business rescue practitioner to have conflict resolution, mediation and negotiation skills. An interviewee referred to these skills as 'political skills', which include the ability to negotiate and mediate an outcome that considers the interests of various affected parties. Conflict resolution, mediation and negotiation skills must be complemented by skills to effect a successful rehabilitation. The interviewees felt that restructuring and turnaround management skills are vital to successfully rescue a financially distressed business.

Four interviewees acknowledged the difficulty for an individual to possess these diverse skills. As a solution to this difficulty, they suggested a joint appointment for rescues where more than one practitioner is appointed. This will ensure that there is sufficient expertise devoted to a business rescue. There was considerable support for joint appointments so that one practitioner complements the weakness of another. The interviewees also suggested the enforcement of joint appointments at the initial phase of a career as business rescue practitioner which will encompass a joint appointment of an inexperienced practitioner with a more experienced managing practitioner. This arrangement will benefit the company in business rescue by ensuring that there are adequate skills for a successful rehabilitation and it will facilitate a transfer of skills to the newly appointed business rescue practitioner. 
An interviewee recommended that businesses comprising a single person, such as a one-man consultancy, must not be a business recue practitioner. In order to be successful, a practitioner must possess proper infrastructure, including office and administrative support. The practitioner must also have a proper support team to ensure that he has access to the necessary legal, accounting, turnaround and mediation skills.

\section{Responsibility for establishing the accrediting body for business rescue practitioners}

An accrediting body is required to establish, implement and maintain the accreditation process for business rescue practitioners. A majority of four interviewees felt that the business rescue profession must be self-regulated. The selfregulatory body must be responsible for the establishment and implementation of accreditation criteria. These interviewees did not support an active role by the government or the CIPC in the regulatory authority for the business rescue profession. They felt that the role of the CIPC must be limited to facilitating the creation of the regulator. However, the CIPC must not oversee the regulator or even serve on it. The regulator should be similar to the South African Institute of Chartered Accountants (SAICA). The Institute is created by an Act of parliament, but government does not play an active operational role. The regulator must serve as the accrediting body and must be self-governing.

One of the interviewees felt that there is no need for a separate accreditation body. His justification for not requiring an accreditation authority was that if the business rescue practitioner requires a professional qualification to be a practitioner, then that member is regulated by a professional body already. For example, if a practitioner plays a legal role, then he is already regulated by the law profession. It will be the same for the accountant. Therefore, there would be no need for a separate accreditation body. However, this minority view does not give due cognisance to the fact that specialist legal and financial skills are required to be a successful business rescue practitioner. An accredited attorney or accountant will require more skills, focusing on corporate law, cash management and turnaround procedures, to be effective as a business rescue practitioner.

In summary, although there are different views relating to the accrediting authority for business rescue practitioners, there is support for an independent authority to be established. The role of the government and the CIPC must be limited to facilitating the establishment of the accrediting body. The regulating authority must be independent and self-regulating rather than managed by government.

\section{Triangulation of quantitative and qualitative research \\ Establishing competencies of a successful business rescue practitioner}

This study utilised triangulation to facilitate the identification of common themes (Leedy \& Ormrod 2001:105). Common
TABLE 2: Competencies of a successful business rescue practitioner.

\begin{tabular}{ll}
\hline Quantitative & \multicolumn{1}{c}{ Qualitative } \\
\hline An accounting qualification & $\begin{array}{l}\text { Specific accounting skills relating to cash } \\
\text { flow management }\end{array}$ \\
Accreditation as a turnaround manager & $\begin{array}{l}\text { Restructuring and turnaround } \\
\text { management skills }\end{array}$ \\
$\begin{array}{l}\text { Effective cash management strategy } \\
\text { skills }\end{array}$ & $\begin{array}{l}\text { Specific legal skills relating to corporate } \\
\text { law and financial distress }\end{array}$ \\
A strong sense of decision-making & Mediation and conflict resolution skills \\
\hline
\end{tabular}

themes for this study were developed by an analysis and comparison of the results of the literature review, questionnaire and interviews.

Table 2 lists the competencies that can be utilised to accredit a business rescue practitioner.

According to Table 2, the two methods approach highlighted certain overlaps in the skills and qualifications that are required to become an effective business rescue practitioner. Results of both methodologies indicate that the tasks of the business rescue practitioner are multidimensional and that it is not sufficient to only possess a single qualification. These findings contradict business rescue legislation that requires a person to have either legal, accounting or business management skills in order to be appointed as a business rescue practitioner (RSA 2008:sec. 138).

The interviewees stressed how important it is that a successful business rescue practitioner should possess restructuring and turnaround skills. A primary objective of the business rescue legislation is to achieve the rehabilitation or turnaround of a financially distressed business. Accordingly, the possession of effective turnaround skills will help to achieve the objective of the legislation. This finding is supported by the quantitative methodology results which indicated that accreditation as a turnaround manager is an important qualification for a successful practitioner.

The interviewees also stated that legal and accounting skills are required to be a successful business rescue practitioner. However, they emphasised that these skills must not be of a general nature and must be focused on corporate recovery, which requires knowledge of corporate law. Additionally, the accounting skills must facilitate the rehabilitation of a business. These skills must be focused on cash flow management and enable a practitioner to generate cash for the distressed business. The findings of the quantitative methodology rated the ability of a practitioner to implement effective cash management strategies as an important skill for a successful business rescue practitioner. The focus on cash management skills is warranted due to the lack of post rescue funding being rated as having the highest impact on a failed business rescue.

In the current research setting, the quantitative and qualitative approaches both highlighted similar trends and principles. 


\section{Conclusion}

\section{Competencies required to be a successful business rescue practitioner}

The most significant contribution of this study is the identification of competencies required to be a successful business rescue practitioner. The responsibilities of business rescue practitioners are multidimensional and they require a variety of competencies. Both the quantitative and qualitative research results emphasised the importance of the business rescue practitioner being competent in cash flow management and in the turnaround of financially distressed businesses. The quantitative methodology results indicated that the most important qualification required to be a successful business rescue practitioner is an accounting qualification and accreditation as a turnaround management professional. The important skills required to be a successful business rescue practitioner are the ability to implement effective cash management strategies and a strong sense of decision-making.

The findings of the qualitative methodology indicated that both legal and financial qualifications are required to be a successful business rescue practitioner. However, the accounting and legal skills must not be of a general nature. They must be focused in the areas of cash flow generation, financial distress and company law. These competencies must be complemented by conflict resolution and mediation skills.

Overall, the core competencies of a successful business rescue practitioner must include effective turnaround management skills and they must have sound legal and accounting knowledge that focus on the rehabilitation of a distressed business. The financial competencies must extend to the ability to effectively manage and generate cash flows.

\section{Acknowledgements Competing interests}

The authors declare that they have no financial or personal relationship(s) that may have inappropriately influenced them in writing this article.

\section{Authors' contributions}

Both authors, R.R. and A.M.S. contributed equally to the article.

\section{References}

Baird, S., 2014, 'An empirical investigation of successful, high performing turnaround professionals: Application of the dynamic capabilities theory', unpublished PhD professionals: Application of the dynamic capabilition,
dissertation, Georgia State University, Atlanta, GA.

Bezuidenhout, P., 2012, 'A review of business rescue in South Africa since implementation of the companies Act (71/2008)', unpublished MBA thesis, NorthWest University, Potchefstroom.

Bharath, T., Panchaegesan, V. \& Werner, I., 2013, The changing nature of chapter 11, working paper no. 461, Indian Institute of Management, Bangalore.

Blazy, R., Martel, J. \& Nigam, N., 2011, 'The choice between informal and formal restructuring: The case of French banks facing distressed SMEs, Internationa Montpellier, pp. 1-32.

Bradstreet, R., 2010, 'The leak in the chapter 6 lifeboat: Inadequate regulation of business rescue practitioners may adversely affect lenders' willingness and the growth of the economy', SA Mercantile Law Journal 22(2), 195-213.

Carter, R. \& Van Auken, R., 2006, 'Small firm bankruptcy', Journal of Small Business Management 44(4), 493-512. https://doi.org/10.1111/j.1540-627X.2006.00187.x
Collett, N., Pandit, N. \& Saarikko, J., 2014, 'Success and failure in turnaround attempts. An analysis of SMEs within the Finnish Restructuring of Enterprises Act',
Entrepreneurship \& Regional Development: An International Journal 26(1), 123Entrepreneurship \& Regional Development: An Intern
141. https://doi.org/10.1080/08985626.2013.870236

Creswell, J.W., 2003, Research design: Quantitative, qualitative and mixed methods approaches, 2nd edn., Sage Publications, London.

Corporate Renewal Solutions, 2012, Turnaround management, viewed 10 October 2017 from http://www.turnaround-sa.com/turnaround $\% 20$ management/turnaround $\%$ 20management.php

Delmarie de List, F. \& Winterton, J., 2005, 'What is competence', Human Resource Development International 18(1), 27-46. https://doi.org/10.1080/136788 6042000338227

Du Preez, W., 2012, 'The status of post commencement finance for business rescue in South Africa', unpublished MBA thesis, University of Pretoria, Pretoria.

Ensor, L., 2014, 'Business rescue under scrutiny as remedies fail to save stricken firms', Business Day Live, 06 August.

Furnam, A. \& Mansi, A., 2011, 'Correlates of self-rated business competencies', International Journal of Business and Management 6(9), 3-13. https://doi. org/10.5539/ijbm.v6n9p3

Gerring, J., 2008, Case study research: Principles and practices, Cambridge University Press, Cambridge.

Guerrero, D. \& De los Ríos, I., 2012, Professional competencies: A classification of international models, Repositorio Instucional Pirhua, Barcelona.

Jarzabkowski, P., Balogun, J. \& Seidi, D., 2007, 'Strategising: The challenges of a practise perspective', Human Relations 60(5), 5-27. https://doi.org/10.1177/ 0018726707075703

Leedy, P. \& Ormrod, E., 2001, Practical research: Planning and design, 7th edn., Pearson Education, Upper Saddle River, NJ.

Levenstein, E., 2011, Business rescue: Problems and pitfalls, corporate governance conference, Werksmans Attorneys, Johannesburg.

Malhotra, N., 2004, Marketing research: An applied orientation, 4th edn., Pearson Education, Upper Saddle River, NJ.

Mindlin, P., 2013, Comparative analysis of chapter six of the South African Companies Act, No. 71 of 2008, viewed 04 May 2016, from https://www.thedti.gov.za/ business regulation/presentations/symposium1of6.pdf

Muller, G.H., Steyn-Bruwer, B.W. \& Hamman, W., 2012, 'What is the best way to predict financial distress of companies?', USB Leaders Lab Agenda 2, 24-25.

Midanek, D.H., 2002, 'How to pick the right turnaround manager', The Journal of Private Equity Fall, 21-24. https://doi.org/10.3905/jpe.2002.320019

Obiajunwa, C., 2014, 'Skills for the management of turnaround maintenance projects', Journal of Quality in Maintenance Engineering 19(1), 61-73. https://doi. ournal of Quality in Maintenance
org/10.1108/13552511311304483

Outecheva, N., 2007, 'Corporate financial distress: An empirical analysis of distress risk', unpublished PhD dissertation, University of St. Gallen Graduate School of Business Administration, St. Gallen.

Pelser, H., 2012, 'SA's business rescue track record', Moneyweb, 04 September.

Pretorius, M., 2012, Business rescue plans-Overview, s.n., s.I.

Pretorius, M., 2013a, 'Tasks and activities of the business rescue practitioner: A strategy as practice approach', South African Business Review 17(3), 1-26.

Pretorius, M., 2013b, 'New business heroes?', Fin24, 03 March.

Pretorius, M., 2014, 'A competency framework for the business rescue practitioner profession', Acta Commercia 14(2), 1-15. https://doi.org/10.4102/ac.v14i2.227

Pretorius, M., 2015, Business rescue status quo report: Final report, Business Enterprises at University of Pretoria, Pretoria.

Pretorius, M. \& Rosslyn-Smith, W., 2014, 'Expectations of a business rescue plan: International directives for chapter 6 implementation', Southern African Business Review 18(2), 108-139.

Republic of South Africa (RSA), 2008, Companies Act, No. 71 of 2008, Government Printer, Pretoria.

Senbet, L. \& Wang, T., 2012, Corporate financial distress and bankruptcy: A survey, viewed 04 March 2016, from http://www.rhsmith.umd.edu/files/Documents/ Centers/CFP/FinancialDistressSurveySenbetWang.pdf

Spencer, L. \& Spencer, S., 1993, Competence at work: A model for superior performance, John Wiley \& Sons, New York.

Teece, D., Pisano, G. \& Shuen, A., 1997, 'Dynamic capabilities and strategic management. The hypercompetitive shift', Organization Science 7(3), 221-242.

Terblanche, D., 2014, With 8\% success rate, something serious amiss with "Business Rescue," viewed 17 January 2016, from http://www.biznews.com/thoughtleaders/2014/02/06/success-rate-just-8-something-serious-amiss-businessrescue/

Visser, A., 2013, 'Business rescue rate has some way to go', Business Day Live, 27 March.

Voller, R., 2011, Business rescue licencing, Companies and Intellectual Property Commission, Pretoria.

Vriesendorp, R. \& Gramatikov, M., 2010, 'Funding corporate rescue: The impact of the financial crisis', INSOL International Solvency Review 19(3), 209-237. https://doi. $\operatorname{org} / 10.1002 /$ iir.188

Wang, M. \& Shiu, H., 2014, 'Research on the common characteristics of firms in financial distress into bankruptcy or recovery', Investment Management and Financial Innovations 2(4), 233-243.

Zikmund, W.G., Babin, B.J., Carr, J.C. \& Griffin, M., 2013, Business research methods, Cengage Learning Custom Publishing, Boston, MA. 